\title{
Robot Penggerak Dua Roda Sebagai Media Pembelajaran Robotik bagi Siswa SMA 05 Barru
}

\author{
Rahimuddin ${ }^{1}$, Syarifuddin Syarif ${ }^{2}$, Rafiuddin Syam ${ }^{3}$, Arzaq $^{4}$, Agung Setiawan ${ }^{4}$, Syahrul \\ AlQadri ${ }^{4}$ \\ Teknik Sistem Perkapalan, Fakultas Teknik Universitas Hasanuddin ${ }^{1 *}$ \\ Teknik Informatika, Fakultas Teknik Universitas Hasanuddin ${ }^{2}$ \\ Teknik Mesin, Fakultas Teknik Universitas Hasanuddin ${ }^{3}$ \\ ${ }^{4}$ Mahasiswa Teknik Sistem Perkapalan, Fakultas Teknik Universitas Hasanuddin ${ }^{4}$ \\ rahimnav@gmail.com
}

\begin{abstract}
Abstrak
Daya kreatif dan inovasi pelajar dapat tercipta melalui proses belajar berterusan dan interaksi lingkungan yang baik. Kegiatan pengabdian ini bertujuan memberikan pelatihan otomasi kepada guru-guru dan siswa-siswi untuk pengembangan kreatifitas bidang pengetahun komputasi dan otomasi robot. Materi pelatihan terdiri atas $60 \%$ praktek dan $40 \%$ teori, menggunakan modul robot dua roda, mikrokontroller, dan aplikasi Arduino. Peserta pelatihan dibagi dalam empat kelompok didampingi oleh masing-masing satu orang mahasiswa tim pengabdian sebagai mentor dalam setiap kelompok. Pelatihan dilakukan di SMA 5 Barru sehari penuh dengan peserta dua puluh orang siswa-siswi terpilih dan dua orang guru pendamping. Hasil kegiatan pelatihan dievaluasi secara random menunjukkan siswa dan guru penamping mampu memahami teknologi komputasi dan otomasi dasar menggunakan media robot penggerak dua roda.
\end{abstract}

Kata Kunci: Robot; Penggerak dua roda; Arduino; Mikrokontroller; Komputasi robotik.

\section{Pendahuluan}

Sekolah merupakan tempat belajar setelah di rumah bagi peserta didik. Pendidikan di sekolah diharapkan dapat membentuk karakter siswa sesuai dengan tujuan pendidikan nasional. Peran Sekolah untuk menciptakan ruang bagi siswa melakukan aktifitas kreatif dan inovatif dalam membangun kepribadian bangsa yang memiliki pengetahuan dan keterampilan menjadi garda terdepan tercapainya tujuan Pendidikan Nasional. Upaya berterusan untuk menciptakan siswasiswa yang berprestasi dilakukan dengan berbagai dimensi kegiatan pendidikan baik formal maupun informal, intra kurikuler maupun ekstra kurikuler, antara lain pengembangan kemampuan hardskill siswa-siswa melalui kegiatan ekstra kulikuler yang dapat meningkatkan kreatifitas dan daya inovasi siswa-siswa.

Kegiatan pengembangan kreatifitas di sekolah-sekolah di luar kota provinsi di bidang teknologi robot belum banyak dilakukan. Sementara penguasaan bidang ini menjadi kebutuhan siswa untuk dapat berkompetisi di masa yang akan datang, bahkan saat ini di beberapa wilayah, pengetahuan otomasi robot sudah mulai diperlombakan untuk tingkat siswa-siswa.

Untuk mengatasi rendahnya kreatifitas siswa khususnya di SMA Negeri 05 Barru dibidang robot, maka upaya awal yang dilakukan adalah memberikan pelatihan dan pengenalan robotika dan 
otomasi kepada guru yang membidangi pengembangan kreatifitas siswa dan guru-guru dibidang ilmu-ilmu eksakta. Pelatihan yang diberikan adalah pengetahuan dasar robot. Pengetahun ini sangat penting untuk mendorong siswa-siswa melakukan kegiatan kreatif dengan memanfaatkan teknologi robot. Pelatihan keterampilan bidang robot telah banyak diberikan kepada siswa-siswa pelajar mulai dari usia sekolah dasar terutama di sekolah-sekolah di kota besar di pulau Jawa. Dalam kegiatan pelatihan ini, Arduino digunakan sebagai perangkat dasar robot yang akan bekerja sebagai pusat pengaturan sistem dalam robot. Penggunaan Arduino dipilih karena Arduino menyiapkan kumpulan program yang lebih banyak dan bersifat gratis, mudah didapatkan melalui internet, perangkat dengan harga yang murah dan telah banyak dikenal di Indonesia.

\section{Arduino, Mikrokonroller, dan Robot}

\section{a. Arduino}

Arduino merupakan perangkat elektronik yang bersifat open-source yang dilengkapi aplikasi editor penyusunan program. Program yang telah disusun dapat di-upload ke dalam mikrokontroller yang telah dilengkapi dengan program kecil pada mikrokontroller sehingga proses upload program tidak memerlukan peralatan tambahan. Perangkat ini dapat membaca masukan sinyal (input) dari sensor dan memberikan luaran sinyal (output), Keluaran ini dapat mengaktifkan motor, menyalakan led atau mematikan led, dll. Sinyal masukan dan luaran diatur sesuai dengan algoritma yang yang diberikan.

\section{b. Mikrocontroller}

Micro-controller adalah perangkat yang terdiri atas processor, memori dan sejumlah pin inputoutput digital maupun analog yang dapat anda kendalikan. Pin-pin tersebut sering disebut GPIO - General Purpose Input Output pins. Dewasa ini dikenal banyak jenis microcontroller $(u C)$ yang diproduksi oleh beberapa industri elektronik, antara lain; Microchip, Motorola, Intel, Texas Instrument, Atmel, dll. Arduino merupakan perangkat elektronik yang terdiri atas board+mikrokontroller, dikembangkan menggunakan Atmel dan dikemas dengan downloader yang sudah diinstall. Kekompakan sistem board Arduino ini dapat menyederhanakan proses penyimpanan/downloading instruksi/code ke dalam IC menggunakan aplikasi IDE Arduino. IDE dapat Anda dapatkan dengan mendownload pada situs www.arduino.cc/en/Main tanpa biaya penggunaan. Arduino juga mengembangkan berbagai modul shield yang dapat dipasang pada microcontroller sehingga Anda akan lebih mudah mengembangkan daberinovasi dengan biaya murah tanpa lebih dulu membuat printed board PCB. Pengembangan codelsketch Arduino menggunakan basis bahasa $\mathrm{C} / \mathrm{C}++$. Selain itu, Arduino memiliki library yang bersifat open source sehingga siapa saja dapat mengembangkan untuk digunakan pada platform Arduino. Beberapa board Arduino yang dikenal di pasaran, antara lain; Arduino Uno, Arduino Due, Arduino Papilio, Arduino Esplora, Arduino Mega, Arduino LyliPad, Arduino Leonardo, dll. [1] 


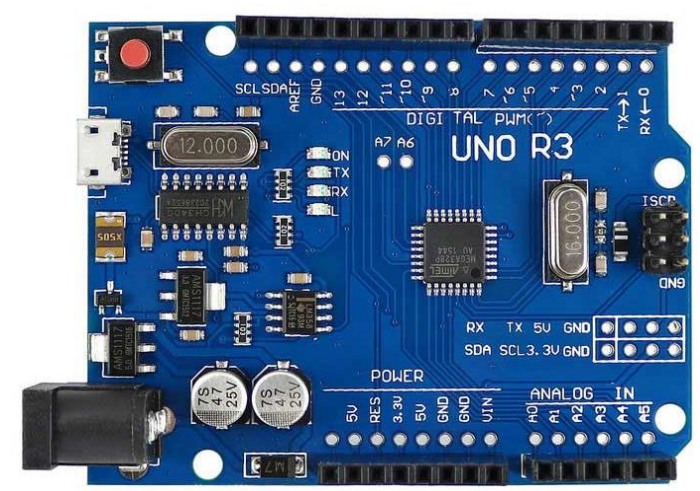

Gambar 1. Mikrokontroller Arduino Tipe UNO R3

\section{c. Kinematika Robot}

Kinematika robot adalah studi analisis pergerakan robot, dalam hal ini robot roda dua terhadap sistem kerangka koordinat acuan yang diam atau bergerak tanpa memperhatikan gaya yang menyebabkan pergerakan tersebut. Model kinematika merepresentasikan hubungan end effector dalam media dua dimensi dengan variabel putaran roda.

Dalam kinematika dikenal istilah forward kinematika dan invers kinematika. Forward kinematika pada robot penggerak dua roda adalah metode untuk menentukan orientasi dan posisi end effector dari besarnya putaran roda robot dalam hal ini perbandingan putaran kedua roda robot tersebut. Sedangkan invers kinematika merupakan kebalikan dari forward kinematika yaitu metode untuk mengetahui nilai sudut yang dihasilkan dari perbandingan putaran kedua roda robot yang diperlukan agar end effector dapat mencapai posisi yang dikehendaki, [2,3].

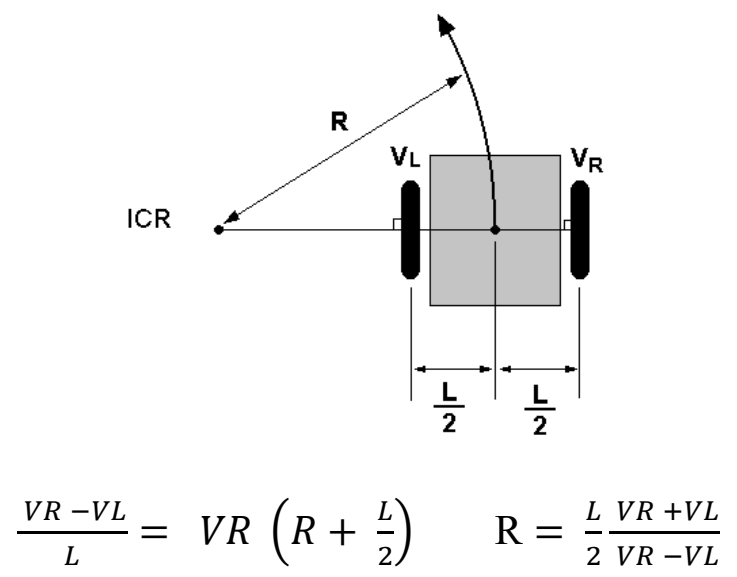

Pergerakan lurus, $\mathrm{R}=$ Tak berhingga, dimana $\mathrm{V}_{\mathrm{R}}=\mathrm{V}_{\mathrm{L}}$

Penggerakan Rotasi, $\mathrm{R}=0$, dimana $\mathrm{V}_{\mathrm{R}}=-\mathrm{V}_{\mathrm{L}}$ 

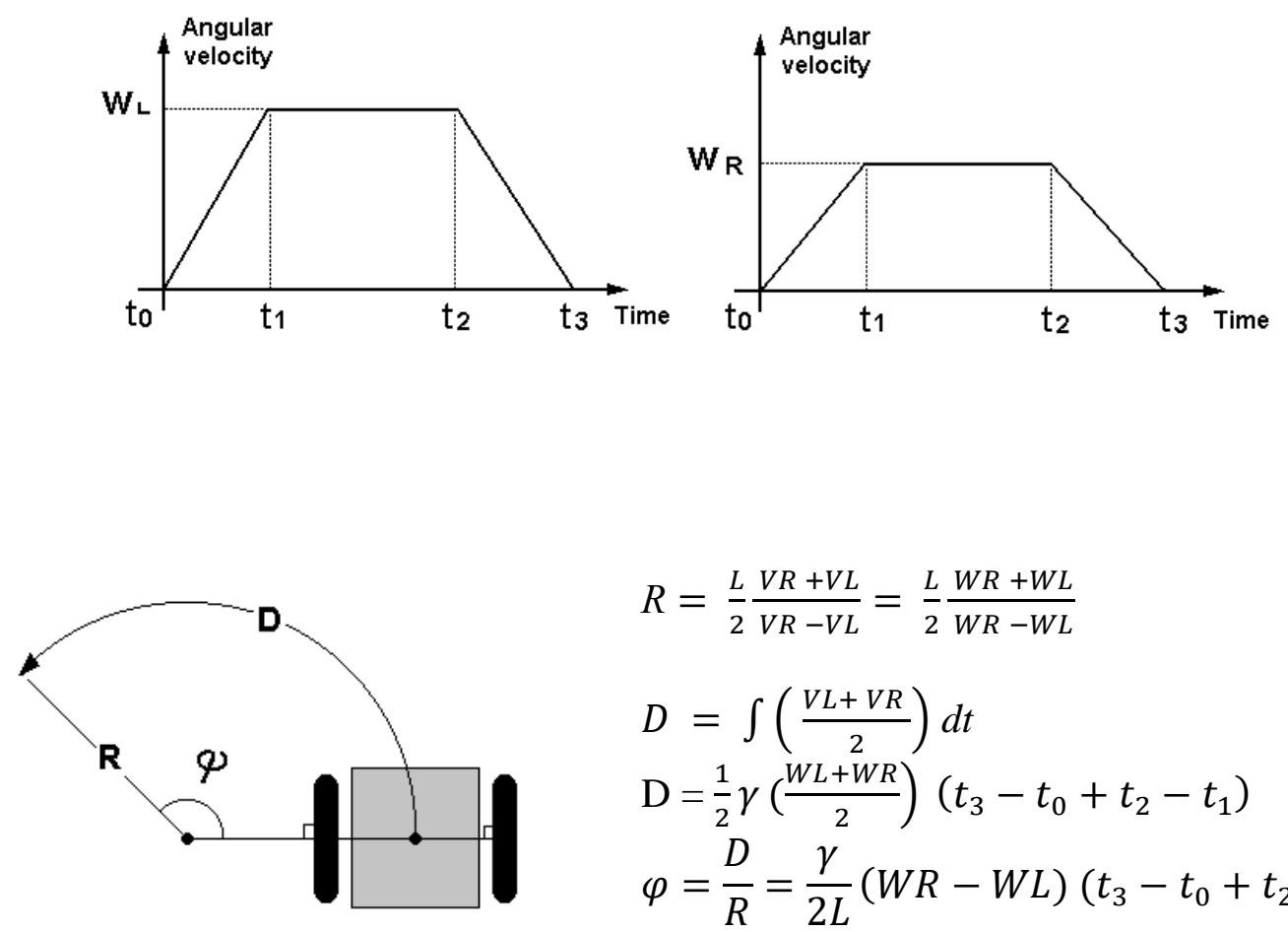

$$
\begin{aligned}
& R=\frac{L}{2} \frac{V R+V L}{V R-V L}=\frac{L}{2} \frac{W R+W L}{W R-W L} \\
& D=\int\left(\frac{V L+V R}{2}\right) d t \\
& \mathrm{D}=\frac{1}{2} \gamma\left(\frac{W L+W R}{2}\right)\left(t_{3}-t_{0}+t_{2}-t_{1}\right) \\
& \varphi=\frac{D}{R}=\frac{\gamma}{2 L}(W R-W L)\left(t_{3}-t_{0}+t_{2}-t_{1}\right)
\end{aligned}
$$

Gambar 2. Kinematika Pergerakan Robot Dua Roda

Keterangan :

$$
\begin{aligned}
& \mathrm{R}=\text { Jari-jari rotasi } \\
& \mathrm{D}=\text { Panjang jalur } \\
& \varphi=\text { Sudut rotasi }
\end{aligned}
$$

\section{d. Motor Servo}

Servo adalah motor yang dapat diperintahkan bergerak ke sudut tertentu. Servo motor memiliki tiga pin yang dapat dibedakan dari warna kabel. Warna kabel umumnya menggunakan warna merah untuk power, hitam untuk ground dan signal biasanya menggunakan warna kuning, beroperasi pada tegangan 4volt - 6 volt. Servo dapat berputar dalam rentang 0-180 derajat dan dapat bergerak presisi mengikuti sinyal perintah yang diberikan. Untuk memutar motor servo, microcontroller memberikan signal pulsa pada periode sinyal tertentu. Motor servo dilengkapi gear sehingga dapat menggerakkan benda dengan beban torque yang diperlukan. Untuk dapat digerakkan dengan sudut yang lebih besar, motor servo perlu dimodifikasi sedemikian rupa sehingga batas sudut dapat diperbesar. Berikut adalah contoh motor servo dan komponen internalnya [4]. 


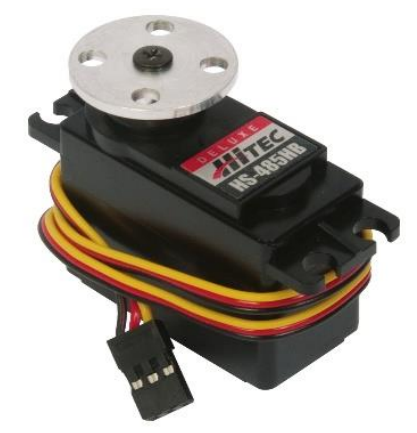

Gambar 3. Motor Servo Jenis Torsi Rendah

\section{e. Sensor Photodioda}

Photodioda adalah suatu jenis dioda yang resistansinya berubah-ubah kalau cahaya yang jatuh pada dioda berubah-ubah intensitasnya. Dalam gelap nilai tahanannya sangat besar hingga praktis tidak ada arus yang mengalir. Semakin kuat cahaya yang jatuh pada dioda maka makin kecil nilai tahanannya, sehingga arus yang mengalir semakin besar. Jika photodioda persambungan $\mathrm{p}$ - $\mathrm{n}$ bertegangan balik disinari, maka arus akan berubah secara linier dengan kenaikan fluks cahaya yang dikenakan pada persambungan tersebut.

Photodioda dapat digunakan sebagai komponen pendeteksi ada tidaknya cahaya. Berbeda dengan diode biasa, komponen elektronika ini akan mengubah cahaya menjadi arus listrik. Cahaya yang dapat dideteksi oleh diode foto ini mulai dari cahaya infra merah, cahaya tampak, ultra ungu sampai dengan sinar-X.

Untuk dapat digunakan pada robot dua roda yang mengikuti garis, maka sistem sensor menggunakan minimal dua sensor photodiode, masing-masing terdiri atas penerima dan pengirim sinyal infrared. Rangkaian pemancar terdiri dari resistor sebagai pembatas arus serta LED sebagai piranti yang memancarkan cahaya. Sedangkan rangkaian penerima terdiri dari resistor sebagai pull-up tegangan dan photodioda sebagai piranti yang akan menerima pantulan cahaya objek. Rangkaian komparator akan membandingkan tegangan input dari sensor dengan tegangan referensi untuk menghasilkan logika ' 0 ' dan ' 1 ' untuk membedakan ada atau tidak ada warna [4-6]. Sensor photodiode seperti pada Gambar 4 berikut:

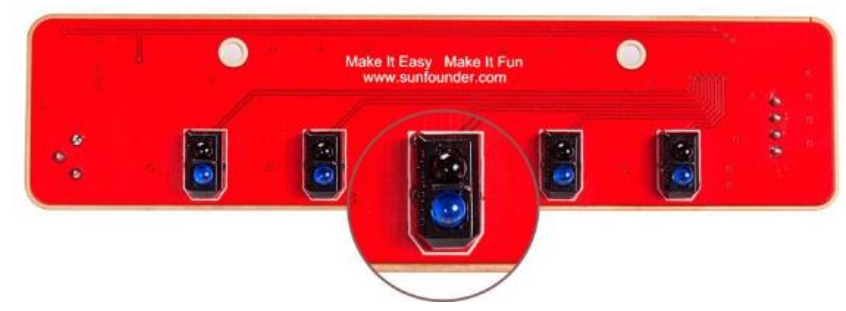

Gambar 4. Sensor Photodioda dengan Lima Unit Sensor

\section{f. Sensor Jarak Ultrasonik}

Sensor jarak ultrasonik digunakan untuk menentukan jarak objek dengan mengukur waktu perambatan suara yang dipantulkan kembali dari objek tersebut. Frekuensi suara berada pada tempat yang masih dalam jangkauan ultrasound, hal ini untuk memastikan arah gelombang suara 
yang lebih terkonsentrasi, karena suara dengan frekuensi yang tinggi akan menghilang sedikit di lingkungan. Sensor jarak ultrasonik terdiri dari dua membran. Membran pertama menghasilkan suara dan memantulkan gema. Pada dasarnya membran tersebut adalah penghasil suara dan mikrofon. Generator suara menghasilkan impuls ultrasonic yang pendek dan memicu timer. Membran kedua mencatat kedatangan impuls suara dan menghentikan timer. Dari timer tersebut dapat memungkinkan untuk menghitung jarak yang dilalui oleh suara dan jarak ke objek adalah setengah jarak yang ditempuh oleh gelombang suara. Sensor ultrasonik memiliki cukup banyak penggunaan dalam kehidupan sehari-hari. Alat ini banyak digunakan untuk mengganti kaset pengukuran dalam mengukur perangkat-perangkat di lokasi konstruksi. Saat ini mobil-mobil telah dilengkapi dengan sensor parkir ultrasonik. Selain mengukur jarak, alat ini hanya dapat menunjukkan keberadaan objek yang berada dalam rentang pengukuran tertentu. Jika pemancar dan penerima ultrasound dipisahkan, kecepatan aliran zat di antara benda-benda tersebut dapat diukur, karena gelombang suara bergerak lebih lambat ke hulu dan sebaliknya[4].

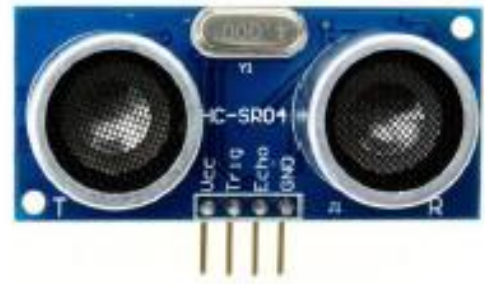

Gambar 5. Sensor Ultrasonik untuk Menentukan Jarak Objek

\section{g. Motor DC dan Roda Kendaraan}

Motor merupakan alat yang memanfaatkan magnet yang membentuk medan gaya dan memanipulasinya sehingga bagian poros motor dapat berputar. Motor terdiri atas rotor (bagian yang berputar) dan stator (bagian yang diam). DC motor menggunakan permanent magnet pada stator, sementara pada rotor terdapat kumparan yang menghasilkan medan magnet apabila dialiri arus listrik. Motor tersebut menggunakan brush sebagai kontaktor ke rotor untuk mengalirkan arus listrik.

Motor Listrik DC atau DC Motor adalah suatu perangkat yang mengubah energi listrik menjadi energi kinetik atau gerakan (motion). Motor DC ini juga dapat disebut sebagai Motor Arus Searah. Seperti namanya, DC Motor memiliki dua terminal dan memerlukan tegangan arus searah atau DC (Direct Current) untuk dapat menggerakannya[6].

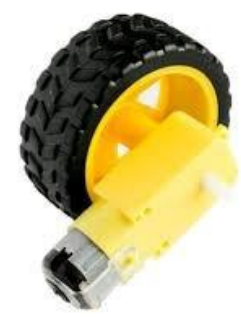

Gambar 6. Motor DC dan Roda Kendaraan 


\section{Metode Pelaksanaan}

a. Persiapan

Pada tahap persiapan, beberapa kegiatan yang dilakukan; menyusun modul pelatihan, menyiapkan alat dan bahan yang dibutuhkan seperti mikrokontroler Arduino, motor servo, sensor ultrasonik, photodioda, motor dan roda, dan motor driver. Peralatan tersebut dirangkai menjadi robot roda dua seperti pada Gambar 7. Program robot diupload ke dalam mikrokontroler dan melakukan pengujiannya. Pada tahap ini tim pengabdian melakukan latihan atau praktek ke peserta disetiap tahap kegiatan menggunakan modul latihan[4].

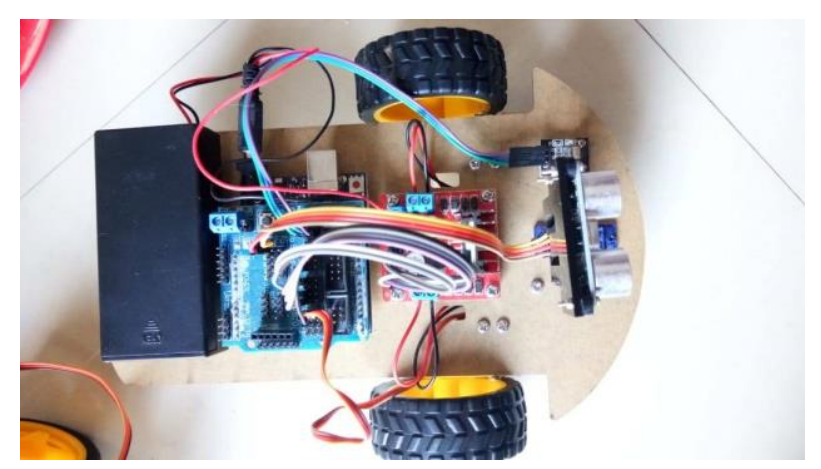

Gambar 7. Robot Kendaraan Dua Roda

b. Pelaksnaan Kegiatan.

Pelaksanaan kegiatan dibagi ke dalam dua tahap; tahap pertama pemberian materi teknik dasar robotik, mikrokontroller Arduino, komponen elektronik pemprograman dasar, oleh ketua tim pengabdian, dan tahap kedua praktek pemasangan modul atau rangkaian elektronik pada modul robot penggerak dua roda. Peserta pelatihan menunjukkan setiap modul robot yang telah dirangkai dan dijalankan di depan peserta kegiatan.
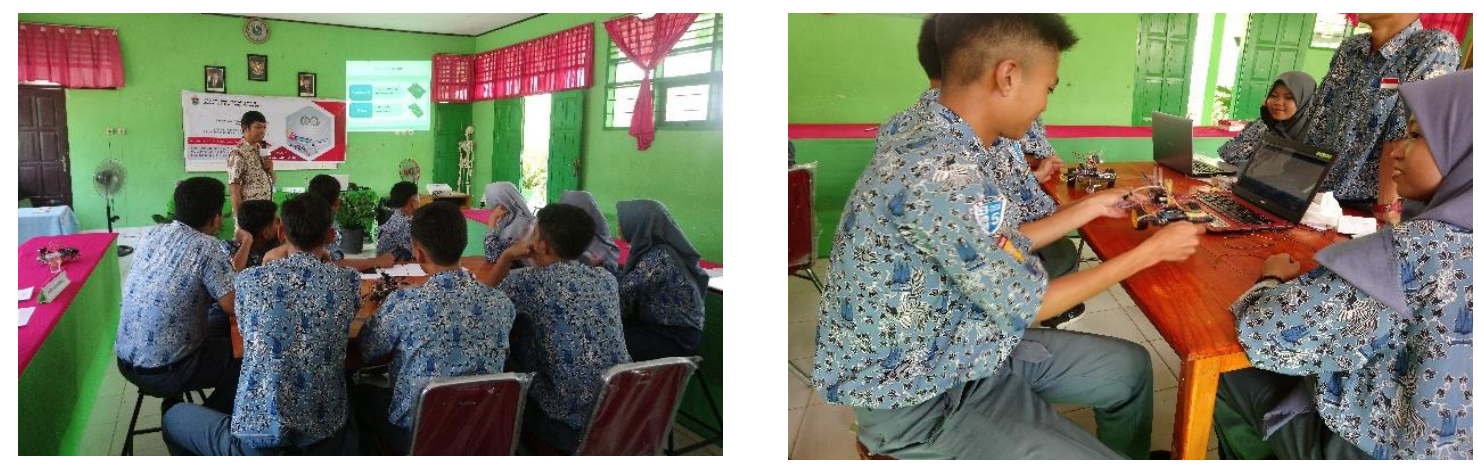

Gambar 8. Suasana Pelatihan yang diikuti Empat Kelompok dengan Masing-masing Kelompok terdiri atas Lima Orang Siswa-siswi 


\section{c. Evaluasi}

Evaluasi hasil pelatihan dilakukan dengan memilih satu kelompok untuk menunjukkan rangkaian elektronik dan robot penggerak dua roda yang dibuat, menginstal aplikasi robotik sederhana, dan menjalankan program robot kendaraan dua roda. Pada kegiatan ini, ketercapaian ditunjukkan dengan memeriksa hasil rangkaian dan cara kerja kelompok yang dipilih serta kemampuan guru dan siswa-siswa menjelaskan dan menjawab tugas yang diberikan dalam pelatihan.

\section{Hasil dan Pembahasan}

Pelatihan ini diikuti oleh siswa-siswa terpilih di SMA 05 Barru sebanyak 20 orang dan 2 orang guru pendamping. Pelatihan dilakukan selama 8 jam yang dibagi kedalam dua sesi. Sesi pertama pemberian materi berupa teknik dasar robotik, mikrokontroller Arduino, dan pengenalan komponen elektronik pemprograman dasar oleh ketua tim pengabdian dan yang kedua latihan pemasangan modul atau rangkaian elektronik (hans on) pada modul robot penggerak dua roda. Dari awal hingga berakhirnya pelaksanaan kegiatan ini, peserta mengikuti setiap rangkaian kegiatan dengan antusias dan baik.

Pada akhir pelaksanaan kegiatan tim pengabdian melakukan evaluasi dengan memilih satu kelompok untuk merangkai ulang modul robot penggerak dua roda dan menjalankan robot tersebut tim juga melakukan tanya jawab secara langsung kepada beberapa siswa peserta pelatihan ini. Dari hasil evaluasi, hasil rangkaian robot penggerak dua roda dari kelompok yang dipilih cukup baik dan dapat dijalankan serta siswa peserta pelatihan mampu menjawab beberapa pertanyaan yang berikan secara langsung tentang seputar pelatihan.

Kekurangan yang dihadapi dalam kegiatan ini adalah keterbatasan waktu kegiatan yang cukup singkat diberikan kepada peserta dan pihak guru sehingga mereka harus belajar mandiri untuk dapat menguasai dan menjalankan robot-robot yang diberikan. Pembelajaran mandiri mereka lakukan menggunakan robot dan modul yang telah diserahkan oleh tim kegiatan.

\section{Kesimpulan dan Saran}

a. Metode yang digunakan dalam pelatihan telah memberikan kesan bahwa belajar teknologi otomasi robot bagi siswa tidak sulit dan menjadi sarana bermain;

b. Peserta pelatihan telah mampu menjalankan program mikrokontroller dasar serta mampu merangkai rangkaian sederhana robot penggerak dua roda.

Berdasarkan kelemahan-kelemahan yang ditemukan, maka tim memberikan beberapa saran agar peserta dapat menguasai materi dengan baik, diantaranya:

a. Menyarankan kepada guru-guru untuk menerapkan kegiatan ekstrakurikuler tentang teknologi komputasi kepada siswa;

b. Pihak sekolah perlu membuat kebijakan pengembangan keterampilan komputasi dan penguasaan pengetahuan robotika dasar melalui pelatihan-pelatihan yang bersifat program tahunan. 


\section{Ucapan Terima Kasih}

Ucapan terima kasih kepada Rektor Universitas Hasanuddin di bawah Lembaga Penelitian Pengabdian Masyarakat yang telah memberikan dukungan dalam pelaksanaan kegiatan ini. Kepala Sekolah dan staf guru-guru SMA Negeri 05 Barru yang telah menyiapkan ruangan, peserta, dan menjamin kegiatan dapat berlangsung dengan baik. Terima kasih pula kepada Dinas Pendidikan Provinsi Sulawesi Selatan yang tmemberikan rekomendasi pentingnya kegiatan ini dilakukan. Apresiasi terima kasih kepada guru-guru dan siswa-siswa SMA Negeri 05 Barru yang telah mengikut pelatihan penerapan robot penggerak 2 roda dengan antusias yang baik, dan kepada seluruh tim yang tergabung dalam pengabdian masyarakat ini.

\section{Daftar Pustaka}

[1] Michael M Beginning Arduino

[2] Rahimuddin, Hasnawiyah, Rivai H, Iskandar Y and Piere Hermanses C. (2018). Design of Omni Directional Remotely Operated Vehicle ( ROV)

[3] John-David Warren, Josh Adams H M. (2009). Arduino Robotics

[4] Rahimuddin. (2014). Mikrokontroller Arduino - Modul Teori dan Praktek pp.76

[5] Oxer J, Blemings H and Oxer J. (2009). Practical Arduino : cool projects for open source hardware

[6] Ayob A, Majid R A, Hussain A and Mustaffa M M. (2012). Creativity Enhancement Through Experiential Learning Adv. Nat. Appl. Sci. 6 94-9 